\title{
A Psychometric Analysis of the Greek Career Adapt-Abilities Scale in University Students
}

\author{
Despina Sidiropoulou-Dimakakou ${ }^{1}$, Katerina Mikedaki ${ }^{2}$, Katerina Argyropoulou $^{3} \&$ Andronikos Kaliris $^{4}$ \\ ${ }^{1}$ Professor of Career Assessment and Guidance, Director of Laboratory of Career Guidance and Counseling, \\ Department of Philosophy, Pedagogy and Psychology, National and Kapodistrian University of Athens, Athens, \\ Greece \\ ${ }^{2}$ M.Sc., Career Counselor-Psychologist, Scientific Collaborator, Laboratory of Career Guidance and Counseling, \\ Department of Philosophy, Pedagogy and Psychology, National and Kapodistrian University of Athens, Athens, \\ Greece \\ ${ }^{3} \mathrm{PhD}$, Career Counselor-Instructor, Scientific Collaborator, Laboratory of Career Guidance and Counseling, \\ Department of Philosophy, Pedagogy and Psychology, National and Kapodistrian University of Athens, Athens, \\ Greece \\ ${ }^{4} \mathrm{PhD}$ Candidate, M.Sc., Career Counselor-Instructor, Scientific Collaborator, Laboratory of Career Guidance \\ and Counseling, Department of Philosophy, Pedagogy and Psychology, National and Kapodistrian University of \\ Athens, Athens, Greece \\ Correspondence: Andronikos Kaliris, PhD Candidate, M.Sc., Career Counselor-Instructor, Scientific \\ Collaborator, Laboratory of Career Guidance and Counseling, Department of Philosophy, Pedagogy and \\ Psychology, National and Kapodistrian University of Athens, Athens, Greece
}

Received: December 4, 2017

Accepted: February 7, 2018

Online Published: August 30, 2018

doi:10.5539/ijps.v10n3p95

URL: http://doi.org/10.5539/ijps.v10n3p95

\begin{abstract}
Based upon substantial research on career adaptability, and on specific cross-cultural validation research of the Career Adapt-abilities Scale (CAAS) (Savickas \& Porfeli, 2012) we recruited a sample of Greek university students $(N=452)$ in order to test further the Greek form of the scale. Confirmatory Factor Analysis models showed that the four-factor structure was supported for the Greek form, comprising four dimensions: concern, control, curiosity, and confidence. The original six items per dimension structure was also maintained. Internal consistency estimates were satisfactory, and test-retest reliability reached acceptable levels. Indications of convergent validity were found as CAAS positively correlated with self-esteem. To further explore for the construct validity of the scale score differences by gender and year of studies were also examined. Overall, the observed differences were found to be in the expected direction. This validity study indicates that CAAS may be safely applied to the Greek students.
\end{abstract}

Keywords: career adaptability, career adapt-abilities scale / Greek form, confirmatory factor analysis, construct validity, self-esteem

\section{Introduction}

In recent years there has been a growing interest in understanding how individuals utilize their self-regulated capacities in order to respond to the changing nature of careers. Due to global demographic and economic trends as well as the complexity of the labor markets, it seems essential for career scholars and counselors alike to assess and develop career adaptability (Dries, van Esbroeck, van Vianen, De Cooman, \& Pepermans, 2012). Career adaptability describes the readiness of individuals to engage in a conscious and continuous exploration of the self and the environment in order to successfully cope with various essential adaptations in their careers (Savickas, 2013). The construct consists of four core adaptability resources (Savickas \& Porfeli, 2012), namely: concern, control, curiosity, and confidence. Specifically, concern is related to one's future perspective, which entails a sense of optimism in relation to a future career. Control relates to one's need to exert influence over the career issues that concern them. Curiosity pertains to the formulation of future career plans through constant exploration of the self and the environment. Confidence is associated with a person's belief in his or her abilities to accomplish necessary career-related actions. 
Overall, the four adapt-abilities enable adjustment to career-related changes, person-environment integration, and successful transitioning across the career life span. In other words, these resources reflect the coping strategies individuals use to manage their careers and lives effectively (Rossier, 2015). It seems that those who possess high levels of career adapt-abilities tend to exhibit behavioral patterns that enable them to attribute optimistic meanings to various career roles (Argyropoulou, 2013), whereas they ensure harmony in their personal and professional lives (Savickas \& Porfeli, 2012). Most importantly, the life design paradigm suggests that, in specific situations, people are able to activate central personal resources such as those related to career adaptability, whereas career interventions can strengthen them leading to a successful life (Rossier, Ginevra, Bollmann, \& Nota, 2017).

\subsection{Literature Review}

There is an abundance of empirical evidence in the related literature highlighting the vital role of career adaptability as a fundamental resource for young people in making decisions autonomously, exploring vocational opportunities and designing their future careers in the face of complex life roles and socioeconomic adversities (Sovet, Annovazzi, Ginevra, Kaliris, \& Lodi, 2018). Relevant studies in adolescents and young people (e.g. university students) have shown that the construct of career adaptability and its dimensions relate positively to several academic, career, and life attitudes and outcomes. Some examples include meaning in life (Yuen \& Yau, 2015), career identity in terms of vocational exploration and identification with career commitments (Porfeli \& Savickas, 2012), job satisfaction (Han \& Rojewski, 2015), academic achievement (Negru-Subtirica \& Pop, 2016), perceived career self-efficacy and career resilience (Sidiropoulou-Dimakakou, Argyropoulou, Drosos, Kaliris, \& Mikedaki, 2015). Santilli, Di Maggio, Marcionetti, \& Grossen (2018) state that positive inner psychological resources such as hope, optimism, resilience, future orientation and career adaptability may be considered relevant for young people today because "they can help them deal with present and future challenges, cope with the current work context and promote positive youth development and life satisfaction" (p. 40).

Based on these assumptions there are recent attempts made by researchers to explore the possible predictive role of career adaptability on several other personal resources (and vice versa) which may affect the youth development, such as courage (e.g. Sovet et al., 2018) or life satisfaction (e.g. Ginevra et al., 2017). For instance, the results of Ginevra et al.'s (2017) in a large sample of Italian high school students $(N=1202)$ aged from 14 to 20 showed that courage partially mediated the relationship between career adaptability and life satisfaction in both boys and girls. The researchers concluded that specific career interventions which promote adaptability and courage could also strengthen life satisfaction in adolescents. Sovet et al. (2018) in a study employing senior high school students from France, Greece and Italy reported that career adaptability predicted courage in adolescents of all three countries.

\subsection{The Greek Context}

Focusing on the Greek context, it seems that a severe change has appeared in the working model which includes flexible forms of work and a deconstruction of the labor law (INE-GSEE, 2015). In addition, in the fourth quarter of 2014 long term unemployment constituted $73 \%$ of total unemployment, the rate of part-time employment increased and wages decreased significantly. Almost the same conditions prevailed in the third quarter of 2015 with the number of unemployed reaching 1.160.522 (Hellenic Statistical Authority, 2015). In February 2016, general unemployment reached $24.2 \%$ (Eurostat, 2016), while especially for young people the situation seemed extremely challenging. The unemployment rate for young people not in education, employment or training (NEET) 15-19 years old was 8.6\%, whereas the rate for the 20-24 year-old age range increased to an alarming $26.5 \%$. In this framework it becomes clear that young adults are forced to adapt not only to job flexibility policies of organizations but also to short-term contracts and the reduction of direct salary costs. Simultaneously they have to conform to other detrimental effects such as the abolition of workforce protective measures, in order to achieve higher employability and maintain their social integration status (Sarigiannidi, 2010; Savickas, 2005).

The specific socio-cultural setting (Petrakis, 2012) also adds to this burden, as in specific cultures such as the Greek one, it is much more difficult to "reset" occupational parameters which may have been achieved via long-lasting efforts, mainly academic training ones -usually a 10 year period including academic preparation for university studies. Moreover, socio-economic variability and job instability seem to suggest to young people negative visions of the future; low perceived possibility of succeeding with future plans; and progressive depreciation of higher education (Nota, Ginevra, \& Santilli, 2015) along with fatalistic attributions towards unemployment (Mylonas et al., 2016). 
Considering these multiple career-related challenges arising for higher education students, both before and after graduation, it seems important to attempt to help them develop inner psychosocial resources and skills as a way to deal successfully with the transition from school to employment; to reach specific academic and career goals (Sung, Turner, \& Kaewchinda, 2013); to enhance employability rates (Mason, Williams, \& Cranmer, 2009); and finally, become successful both at work and life (Tran, 2013). Psychological resources such as career adaptability may help individuals go through the career development process, overcome career barriers and difficulties and adapt to unforeseen changes in career-related roles (Nota et al., 2015; Savickas \& Porfeli, 2012).

Assessing career adaptability resources in Greek young adults would be essential for two main reasons: Firstly, career professionals would be able to detect whether career adaptability of young people has been affected by the distressed socioeconomic climate and secondly, reconsider, if necessary, the aims and methods of career counseling when addressing issues of this group.

\subsection{Psychometric Properties of the Career Adapt-Abilities Scale (CAAS; Savickas \& Porfeli, 2012)}

The Career Adapt-Abilities Scale (CAAS; Savickas \& Porfeli, 2012) seems to be a useful instrument for measuring career adaptability resources as there is clear evidence in various countries and contexts for its validity and reliability. For instance, the psychometric properties of the Portugeuse form of the scale (Duarte et al., 2012) were satisfactory for a sample of 916 participants (employed and unemployed adults and university students). The total reliability Cronbach's $\alpha$ coefficient was .90 and for the subscales ranged from .69 to .79 . The fit indices of this research were $R M S E A=.061, S R M R=.049$ and $C F I=.97$, which were in conformity with the established fit criteria. Pouyaud, Vignoli, Dosnon, \& Lallemand (2012) adapted CAAS in France employing a sample of 609 students. They demonstrated adequate psychometric characteristics as $\alpha$ for the total score was .85 and for the subscales varied from .64 to .78 whereas the fit indices for that sample were also acceptable. Analyzing data from 296 Chinese students, Hou, Leung, X. Li, Li, \& Xu (2012) found a total $\alpha$ coefficient of .89 and subscale reliabilities varying from .64 to .79 . Confirmatory factor analysis showed that data for CAAS China form fit the theoretical model very well. The Australia CAAS form also had very good internal consistency reliabilities (around .90, $N=555$ ), similar to those of the international sample, while CFA showed that the data conformed to the theoretical model (Tolentino, Garcia, Lu, Restubog, Bordia, \& Plewa, 2014)

Convergent validity of CAAS has been supported in many studies through strong positive relations of the instrument with a plethora of work- and life-related variables such as self-esteem, career resilience, quality of work and work stress, quality of life, breadth of career interests, orientation to happiness, perceptions of growth in one's career, emotional intelligence, well-being, and career success (Ashton, 2013; Bimrose \& Hearne, 2012; Coetzee \& Harry, 2014; Creed, Fallon, \& Hood, 2009; Johnston, Luciano, Maggiori, Ruch, \& Rossier, 2013; Koen, Klehe, \& van Vianen, 2012; Maggiori, Johnston, Krings, Massoudi, \& Rossier, 2013; Rudolph, Lavigne, \& Zacher, 2017; Soresi, Nota, \& Ferrari, 2012; Zacher, 2014a; van Vianen, Klehe, Koen, \& Dries, 2012).

\subsection{Aims of the Study}

The primary aim of this study was to explore the suitability of the Career Adapt-abilities Scale (Savickas \& Porfeli, 2012) to a population of Greek university students, taking into account (a) the potential positive effects of boosting career adaptability in young people world-wide and (b) the precarious state of both the economy and the labor market in Greece. For this reason, first, we tested the four-factor structure of CAAS with 24 items included through Confirmatory Factor Analysis. Second, we examined construct validity by comparing student groups that would be theoretically expected to differ (Anastasi \& Urbina, 1997) in CAAS scores. Comparisons between groups were performed based on gender and semester of study. Based on previous research in a similar socioeconomic context (Duarte et al., 2012), women were expected to report higher scores on career adaptability dimensions than men.

Regarding study periods, it was expected that students of later years would report higher scores on career adaptability because career maturity seems to foster as age advances (Hirschi \& Läge, 2007; Patton \& Creed, 2001). Students closer to entering the labor market than their younger counterparts may very well be more concerned regarding their occupational future.

Another goal of the present research was to investigate the relationship between self-esteem and CAAS dimensions in an attempt to gather validity evidence for the Greek form of the scale. In this study higher scores of career adaptability were expected to relate to higher scores of self-esteem. Relevant literature points to self-esteem as a critical independent variable accounting for the variance in adaptability (Duffy, 2010). McArdle, Waters, Briscoe, and Hall (2007) found a positive correlation between adaptability and self-esteem in 416 unemployed Australians while van Vianen et al. (2012) reported a significant correlation between the two 
variables in a sample of 465 university students from the Netherlands. Very recently, Ataç, Dirik, \& Tetic (2017) revealed that career adaptability was predicted by self-esteem in a sample of young adults.

\section{Methods}

\subsection{Participants}

The sample consisted of 452 undergraduate students studying at different university schools (Athens region) and specifically, at the National and Kapodistrian University of Athens (43.4\%), at Panteion University of Social and Political Sciences (13.1\%), at the National Technical University of Athens (12.4\%), at the Technological Educational Institute of Athens (10.6\%) and other (20.5\%) [Harokopion University, Athens University of Economics and Business, University of Piraeus Agricultural University of Athens]. All students were Greek nationals who had taken formal Panhellenic exams to enrol university. Regarding gender, 154 students (34.1\%) were male while $298(65.9 \%)$ were female. The age of the participants ranged from 18 to 46 with a mean $(M)$ of 21.1 years and a standard deviation $(S D)$ of 3.56. Students of all semesters ranging from first to tenth participated in the survey, Most students attended the sixth semester $n=103(22.8 \%)$; the fifth semester was attended by 81 students $(17.9 \%)$; the third semester was attended by 76 students $(16.8 \%)$; the first semester was attended by 52 students (11.5\%) and 44 students attended the eighth semester (9.7\%).

Each questionnaire was screened by the second author in order to guarantee that no missing data occurred. As a result there were only few missing data which were substituted by the mean score of the item (Graham, 2009).

\subsection{Procedure}

Our cross-sectional survey lasted approximately 9 months. Questionnaires were administered to university students in the city of Athens. Cluster sampling was applied as participants represented entire classes. Questionnaires were completed at the end of lectures and after initial permission. Participation in the study was voluntary and informed consent was acquired before the survey administration. No award was given for participating in this research. Confidentiality of the data was maintained throughout all research stages. Standard procedure of back translation was followed (van de Vijver \& Leung, 1997). The instruments of the survey were translated into Greek (all translations were done by the second author and revised by the first author) and back translations were carried out by a qualified native English translator. The back translation was approved by the constructor of CAAS, Professor Mark Savickas.

\subsection{Measures}

\subsubsection{Career Adaptability}

The CAAS international form consists of 24 items yielding a total score of career adaptability (item examples: "Preparing for the future", "Taking responsibility for my actions", etc.). These 24 items are divided equally into four subscales that measure adaptability traits of Concern, Control, Curiosity and, Confidence. Participants report the degree to which they possess each career adapt-ability on a 5-point Likert-type scale $(1=$ not strong, $5=$ strongest) for each of the 24 items. High internal consistency reliability (Cronbach's $\alpha$ ) has been reported (Savickas \& Porfeli, 2012) for the international total scale (.92) and the sub-scale scores (concern, .83, control, .74, curiosity, .79, and confidence, .85).

\subsubsection{Self-Esteem}

To measure self-esteem, Rosenberg's self-esteem questionnaire (1965) was used. This questionnaire comprises 10 items (e.g., "On the whole, I am satisfied with myself", "At times I think I am not good at all”, etc.) aimed at measuring individual's global self-esteem by a binary scale ("Yes" or "No").

\subsubsection{Lie Scale}

A Lie Scale derived from the Eysenck Personality Questionnaire for adults was also employed (Dimitriou, 1986), comprising 19 items (item examples are "If you say you will do something do you always keep your promise, no matter how inconvenient it might be to do so?" and "Are all your habits good and desirable ones?"). This Lie Scale score was made available so that we might use in the analysis as a covariate score in order to neutralize any possible social desirability effect, if any detected.

\subsubsection{Demographics}

An improvised questionnaire was employed to gather data on students' gender, age and semester of study. 


\section{Results}

\subsection{Psychometric Properties of the Career Adapt-Abilities Scale - Greece}

\subsubsection{Reliability estimates}

Reliability analysis (internal consistency) for the CAAS was employed and Cronbach's $\alpha$ was satisfactory both for the total scale $(\alpha=.88)$ and for the subscales (concern: $\alpha=.81$, control: $\alpha=.73$, curiosity: $\alpha=.73$, and confidence: $\alpha=.80$ ). The above reliability estimates closely match those of the international CAAS (Savickas \& Porfeli, 2012, Table 1, p. 667). Test-retest reliability was also assessed by administering the scale twice in a sample of 40 individuals through a five-week interval. Pearson's $r$ was employed for this analysis and yielded satisfactory test-retest reliability indices (concern: $r=.82$, control: $r=.77$, curiosity: $r=.69$, and confidence: $r$ $=.64)$. For the total scale, test-retest reliability was $r=.87$.

\subsubsection{Confirmatory Factor Analysis}

The structure of CAAS Greek form was tested by imposing data gathered from the 24-item scale on confirmatory factor analysis using LISREL 8.30. Maximum Likelihood (ML) method was used to examine the factorial structure. In particular, three different models were examined; a single-factor model, a four-factor model as proposed by Savickas and Porfeli (2012) and another one, comprising 4 factors with error covariances included. More specifically, we took into account error covariances solely within the factors and released the greatest ones which existed between items of the same factor (Table 1). This practice does not imply interdependent factor modeling as factors still remain orthogonal (Mylonas, Lawrence, Zajenkowska, \& Bower Russa, 2017).

The modified model (d) was tested in order to reduce influence of errors within factors which are usually caused by items which are very similarly worded or items prone to social desirability (Brown \& Moore, 2012). This model was finally endorsed suggesting a good fit of our data with the original theory. Specifically, as $\mathrm{Hu}$ and Bentler suggest (1999), the chi-square over degrees of freedom ratio should reach 3 or less, CFI and GFI should reach .90 or more, and RMSEA should not exceed .08 , for an acceptable model fit. According to the results depicted on Table 1, the modified four-factor model (d) reached a better fit to real data as $\chi^{2} / \mathrm{df}$ was 2.626 although $\chi^{2}$ remained statistically significant $(p<.001)$; RMSEA was acceptable $(.06)$ as was $C F I$ as well (.89). Lastly, $\Delta \chi^{2}$ reached 309.08 and was statistically significant showing model improvement with Tucker-Lewis indices concurring and revealing much larger improvement than the one observed when comparing the single-factor factor model with the non-modified 4-factor model. Additionally, the non-zero Tucker-Lewis Index value (.42), as reached when comparing the non-modified with the modified 4-factor model, confirmed the above improvement findings. In all, although the non-modified (c) 4-factor model seemed to be adequately yielding promising values, the modified 4-factor model was more appropriate, allowing for better explanatory power.

Table 1. Confirmatory Factor Analysis results; CAAS-Greek form

\begin{tabular}{llllllllll}
\hline Model & $\chi^{2}$ & $D f$ & $\chi^{2} / d f$ & RMSEA & GFI & CFI & $T L I$ & $\Delta \chi^{2}$ & $\Delta d f$ \\
\hline a.Independence & $3648.24^{*}$ & 276 & 13.22 & - & - & - & - & - & - \\
b.Single-factor & $1836.82^{*}$ & 252 & 7.289 & 0.120 & 0.75 & 0.64 & $0.49^{\mathrm{b}-\mathrm{a}}$ & $1811.42^{*}$ & 24 \\
c.4-factor & $934.19^{*}$ & 246 & 3.797 & 0.079 & 0.85 & 0.81 & $0.56^{\mathrm{c}-\mathrm{b}}$ & $902.63^{*}$ & 6 \\
d.4-factor & $625.11^{*}$ & 238 & 2.626 & 0.060 & 0.90 & 0.89 & $0.42^{\mathrm{d}-\mathrm{c}}$ & $309.08^{*}$ & 8 \\
(modified) & & & & & & & $0.74^{\mathrm{d}-\mathrm{b}}$ & $1211.71^{*}$ & 14 \\
\hline
\end{tabular}

${ }^{*}$ All statistically significant at the .001 level 


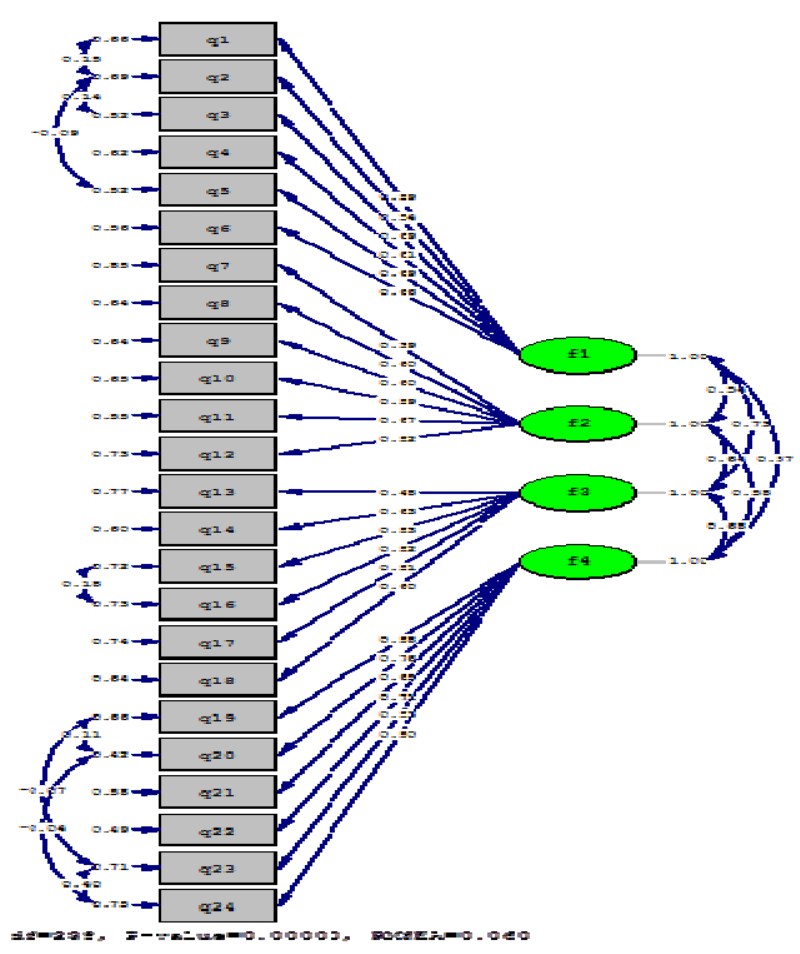

Figure 1. The modified four-factor model for CAAS - Greek form 
Table 2. Items, means, standard deviations and CFA loadings of the 24 items of CAAS

\begin{tabular}{lcccc}
\hline Items & $\boldsymbol{M}$ & $\boldsymbol{S D}$ & loadings & $\boldsymbol{\alpha}$ \\
\hline 1st factor: Concern & & & & 0.81 \\
\hline Q 1.Thinking about what my future will be like & 3.19 & 0.99 & 0.59 & \\
Q 2.Realizing that today's choices shape my future & 3.44 & 1.00 & 0.54 \\
Q 3.Preparing for the future & 3.10 & 0.97 & 0.69 \\
Q 4.Becoming aware of the educational and vocational choices that I & 2.91 & 1.03 & 0.61 \\
must make & 3.23 & 1.01 & 0.69 \\
Q 5.Planning how to achieve my goals & 3.75 & 0.97 & 0.66
\end{tabular}

$2^{\text {nd }}$ factor: Control

Q 7.Keeping upbeat

$\begin{array}{lll}3.30 & 1.17 & 0.39\end{array}$

Q 8.Making decisions by myself

$\begin{array}{lll}3.59 & 0.98 & 0.60\end{array}$

Q 9.Taking responsibility for my actions

$\begin{array}{lll}3.92 & 0.92 & 0.60\end{array}$

Q 10.Sticking up for my beliefs

$\begin{array}{lll}3.75 & 0.93 & 0.59\end{array}$

Q 11.Counting on myself

$\begin{array}{lll}3.74 & 0.92 & 0.67\end{array}$

Q 12.Doing what's right for me

$\begin{array}{lll}3.26 & 0.94 & 0.52\end{array}$

$3^{\text {rd }}$ factor: Curiosity

0.73

Q 13.Exploring my surroundings

Q 14.Looking for opportunities to grow as a person

$\begin{array}{lll}3.04 & 0.97 & 0.48\end{array}$

Q 15.Investigating options before making a choice

$\begin{array}{lll}3.43 & 0.98 & 0.63\end{array}$

Q 16.Observing different ways of doing things

$\begin{array}{lll}3.33 & 1.05 & 0.53\end{array}$

Q 17.Probing deeply into questions I have

$\begin{array}{lll}3.13 & 0.97 & 0.52\end{array}$

Q 18.Becoming curious about new opportunities

$\begin{array}{lll}3.08 & 1.06 & 0.51\end{array}$

$\begin{array}{lll}3.57 & 0.98 & 0.60\end{array}$

$4^{\text {th }}$ factor: Confidence

Q 19.Performing tasks efficiently

Q 20.Taking care to do things well

Q 21.Learning new skills

Q 22.Working up to my ability

Q 23.Overcoming obstacles

Q 24.Solving problems

0.80

Thus, confirmatory factor analysis (CFA) showed that the CAAS-Greece data fit the theoretical model well. The indices found in this CFA analysis compared favorably to those of the CAAS-International model (RMSEA $=.053$ and $C F I=.92$, see Savickas \& Porfeli, 2012, Table 2). The modified four-factor model is presented in Figure 1. The four factors (concern, control, curiosity, confidence) along with the items comprising each factor (concern: q1-q6, control: q7-q12, curiosity: q13-q18, confidence: q19-q24), are depicted confirming the originally suggested structure of CAAS.

\subsection{Correlations among Career Adaptability, Self-Esteem and Social Desirability}

There was no association between self-esteem and social desirability. However, the latter variable was slightly associated to an overall career adaptability score $(r=.20, p<.01)$. A significant positive correlation was found between the overall career adaptability and self-esteem $(r=.24, p<.01)$. Both dimensions of "control" $(r=.30)$ and "confidence" $(r=.21)$ were positively correlated with self-esteem at the .01 significance level.

To test for possible differences in correlation scores between self-esteem and career adaptability two correlation tables were employed; the first correlation table entries were corrected for social desirability effects (Mylonas, Furnham, \& Country Collaborators, 2014, p. 86) and were then compared to the second unadjusted correlation 
table. Using $z$-tests (following Fisher's $z$ transformation) no difference was found between initial and adjusted values (Mylonas et al., 2012), so there was no need to use the lie scale scores as a covariate).

Convergent criterion validity of the CAAS / Greek form was partly supported when these measures (total CAAS, "control" and "confidence") were related to self-esteem, possibly sharing some common variance. We expected the aforementioned constructs to be positively related as self-esteem is a rather stable trait which directs people's cognitions, affective states, and behaviors, which are important to their career outcomes (van Vianen et al., 2012).

\subsection{Gender and Career Adaptability}

To find out whether career adaptability scores differed significantly between male and female students of the sample, $t$-tests were applied. The analysis demonstrated that female students scored significantly higher than male students in the "Concern" subscale $\left(M_{\text {females }}=20.28, M_{\text {males }}=18.36, t(450)=4.611, p<.001\right)$ as well as in the "Curiosity" subscale $\left(M_{\text {females }}=19.97, M_{\text {males }}=18.83, t(450)=2.953, p<.01\right)$. It seems that female students start being interested in their career and seeking for career opportunities earlier than male students during their studies. Thus, they are more motivated and directed to future career prospects.

\subsection{Associations between Semester of Study and Career Adaptability}

The semester data were classified in three categories. The first group referred to both 1st year students and 2nd year students. These two groups were unified for the analysis because they both were at their initial stage of their studies. According to the Greek reality this means that they are not yet concerned with their occupational futures. Another group comprised of 3rd year students who were in the middle of their studies and finally, another group referred to students who were about to graduate, that is, at the 4th year of studies or higher. One way analysis of variance (ANOVA) employing post-hoc analysis (Scheffé criterion) showed a statistically significant difference between students of the first year-group (initial stage of studies, $M_{\text {initial }}=18.95, S D=4.02$ ) and those who were in the middle of their university life ( $3^{\text {rd }}$ year-students, $\left.M_{\text {third-year }}=20.32, S D=4.37\right)$ for the "Concern" dimension, in favor of third-year students $(p<.01)$.

\section{Discussion}

The main goal of this research was to explore the suitability of CAAS for the Greek context. The four factor structure of the scale was confirmed while the six items per dimension were maintained as well. Summing up the results revealed that CAAS - Greek form could be safely applied to the population of the Greek University students.

\subsection{Psychometric Properties of the Career Adapt-Abilities Scale - Greece}

Deploying confirmatory factor analysis, we confirmed the original model structure proposed by CAAS developers (Savickas \& Porfeli, 2012), a finding which expands the cross-national measurement equivalence of this scale. Both internal consistency estimates and test-retest reliability scores were adequate and similar to those of the international CAAS. Linguistic explication was as accurate as possible and resembled that of the initial international form in order to avoid misinterpretation

The above results provide us with concrete evidence about the construct validity and reliability of the CAAS Greek form. Additional indications of validity of the scale were generated from a survey with Greek university students, where strong positive associations were detected among career adaptability, career resilience and self-efficacy in career planning (Sidiropoulou-Dimakakou et al., 2015). Another recent piece of research (Sovet et al., 2018) on cross-cultural grounds, deployed samples of adolescents from France, Greece, and Italy to examine the predictive role of career adaptability on courage. Results revealed that CAAS may also be suitable for this population, as career adaptability resources uniquely accounted for $31 \%$ of the variance of courage in the Greek adolescents. Furthermore, good reliability estimates (Cronbach's $\alpha$ ) revolving around $\alpha=.90$ for the CAAS total score and its subscales were demonstrated in a study including students of both general and vocational upper secondary schools in Greece (Argyropoulou, Tsikoura, \& Kaliris, 2017). In the same research moderate to strong positive relations were detected among the dimensions of career adaptability and those of perceived self-efficacy in career planning as measured by a recently developed instrument (Sidiropoulou-Dimakakou, Mylonas, \& Argyropoulou, 2015).

Therefore, future research on CAAS may include additional populations (e.g. labor force and other occupations, adolescents) to further test its factorial equivalence corroborating the utility of the scale for research purposes. Moreover, testing measurement invariance across different samples could provide more robust evidence of construct validity. 


\subsection{Correlations between Career Adaptability and Self-Esteem}

A significant positive relationship of the total CAAS with self-esteem $(r=.24, p<.01)$ was confirmed. Statistically significant positive correlations found between self-esteem and the "control" subscale $(r=.30$, $p<.01)$ as well as the "confidence" subscale $(r=.21, p<.01)$.

In accordance with this result, van Vianen et al. (2012) found that self-esteem correlated the highest with "control" subscale $(r=.52, p<.01)$. Such an observed relation may be grounded in that "control" sub-dimension is measured with items such as "Sticking up for my beliefs" and "Counting on myself" which refer to self-reliance. It is also worth mentioning that core self-evaluations theory (Judge, Locke, \& Durham, 1997) postulates that self-esteem is strongly associated with locus of control (people's belief that they can control events that affect them). Both self-esteem and locus of control constitute parts of the higher-order construct of core-self evaluations, representing the fundamental evaluations that people make about their competence, worthiness and their functioning in their environment (Judge, van Vianen, \& De Pater, 2004).

Researchers might further examine in the future the relationship between the "control" dimension and self-esteem as career adaptability construct reflects - at least in part - people's need and ability to take control of their career and life despite various socioeconomic adversities, transitions or traumas.

Table 3. Correlations between self-esteem and career adaptability dimensions

\begin{tabular}{llllll}
\hline & Self-esteem & Concern & Control & Curiosity & Confidence \\
\hline Self-esteem & 1 & & & & \\
Concern & $.12^{* *}$ & 1 & & & \\
Control & $.30^{* *}$ & $.38^{* *}$ & 1 & & \\
Curiosity & $.12^{* *}$ & $.54^{* *}$ & $.45^{* *}$ & 1 & 1 \\
Confidence & $.21^{* *}$ & $.43^{* *}$ & $.48^{* *}$ & $.50^{* *}$ & 1 \\
\hline
\end{tabular}

Note. $N=452$.

**Correlation is significant at the 0.01 level (2-tailed).

\subsection{Differentiations in Career Adaptability Based on Gender}

The finding that females were more concerned and curious about their future career than their male counterparts was also confirmed in the Portuguese adaptation of the Career Adapt-Abilities Scale (Duarte et al., 2012). This result can be interpreted by the fact that females tend to mature sooner than males (Cole \& Cole, 2002), whereas research reveals that women in the first steps of their career seem to look for work challenges that entail larger amounts of responsibility and control (Sullivan \& Mainiero, 2008). Thus, young women may show a more concrete orientation towards future career prospects than men and explore career opportunities already starting from the university life.

\subsection{Differentiations in Career Adaptability Based on Semester of Study}

Third-year students, as expected, reported higher scores at "concern" dimension than their younger colleagues, a result contributing to the construct validity argument for CAAS. In the current research, the relationship between semester of study and career adaptability is probably grounded on the fact that third-year students are a step closer to entering the labor market and are urged to make critical decisions about their future (i.e. choosing a major, seeking for graduate studies etc.).

\subsection{Limitations}

A major limitation in our research was that the sample consisted only of university students. Further studies should be conducted including various samples of employed and unemployed people to gather data regarding the role of work experience on career adaptability levels. Additionally, future research aiming at further supporting the validity of CAAS should support convergent validity providing more data about its relations with multiple career management skills (e.g. self-efficacy, hope, career resilience, courage, job crafting) and outcomes (e.g. job satisfaction, job performance, well-being, balance between life and work roles). Discriminant validity should also be examined by studying relationships of the career adaptability sub-dimensions with relevant career constructs with which are hypothesized to be negatively associated, such as career decision-making difficulties. Finally, it would be of great interest to examine the economic crisis impact on youth's career adaptability 
dimensions while they enter the stage of exploring career opportunities through a turbulent and challenging Greek socioeconomic context.

\section{Conclusion}

Based on the results of this research we can consider CAAS - Greek form equivalent to the international form in terms of psychometric characteristics and factor structure. The good psychometric properties of the scale, prompt us to consider it appropriate for exploring career adaptability levels of university students in Greece, constructing and assessing career counseling interventions focusing on career adaptability enhancement. Students need to develop career adaptability resources such as concern, control, curiosity and confidence so as to be prepared to enter the labor market and manage expected or unforeseen career transitions. We contend that career-related interventions targeting to reinforcing the above psychosocial resources to students should be a fundamental goal of the Greek university curricula.

\section{Implications for Practice}

The aforementioned results suggest possibilities for future use of CAAS for career counseling practice. It is noteworthy that the Career Counseling Research and Assessment Centre (recently Career Guidance and Counseling Laboratory) of the National and Kapodistrian University of Athens has developed a comprehensive program to enhance career adapt-abilities in university students (Sidiropoulou-Dimakakou, Argyropoulou, Mikedaki, \& Tsakanika, 2013) placing emphasis on creating a future self-image in relation to career goals (Argyropoulou, 2013). The program consists of 7 one-hour sessions. In the first session, a 15 -minute video is displayed, usually an excerpt of a film with career adaptability as a central issue. In each following session, the counselor presents a career adaptability resource and, then, participants work in teams in order to boost the corresponding skill through experiential activities.

The implementation of the program was successful according to feedback given by the participating students but it is crucial to test its effectiveness in the student population through an experimental design. Career Adapt-abilities Scale Greek form could be administered to participants before the beginning of the program, in the middle and in the end to assess possible fluctuation in students' career adapt-abilities.

\section{References}

Anastasi, A. \& Urbina, S. (1997). Psychological testing (7th ed.). Upper Saddle River, NJ: Prentice-Hall.

Argyropoulou, K. (2013). E epaggelmatike prosarmostikotita os proepothese yia mia stadiodromia me noema [Career adaptability as prerequisite for a meaningful career]. Epitheorese Simvouleftikis ke Prosanatolesmou, 102, 26-35.

Argyropoulou, K., Tsikoura, I., \& Kaliris, A. (2017). Career management skills of students in general and vocational upper-secondary schools in Greece: Career adaptability and self-efficacy in career planning. Baltic Journal of Career Education and Management, 5(1), 7-21. ISSN 2345-0193 (Print), ISSN 2538-7189 (Online)

Ashton, M.W. (2013). Career adaptability in emerging adults: A foundation of personal growth (Unpublished Doctoral Dissertation). Texas Tech University, U.S.A.

Ataç, L. O., Dirik, D., \& Tetic, H. T. (2017). Predicting career adaptability through self-esteem and social support: A research on young adults. International Journal for Educational and Vocational Guidance. Advanced online publication. https://doi.org/10.1007/s10775-017-9346-1

Bimrose, J., \& Hearne, L. (2012). Resilience and career adaptability: Qualitative studies of adult career counselling. Journal of Vocational Behavior, 81(3), 338- 344. Retrieved from https://doi.org/10.1016/j.jvb.2012.08.002

Brown, T. A. \& Moore, M. T. (2012). Confirmatory factor analysis. In R. Hoyle (Ed.). Handbook of Structural Equation Modeling (pp. 361-379). New York, NY: The Guilford Press.

Coetzee, M. (2008). Psychological career resources and subjective work experiences of working adults: a South African survey. South African Journal of Industrial Psychology, 34(2), 32-41. https://doi.org/10.4102/sajip.v34i2.491

Coetzee, M. \& Harry, N. (2014). Emotional intelligence as a predictor of employees' career adaptability. Journal of Vocational Behavior, 84, 90-97. https://doi.org/10.1016/j.jvb.2013.09.001 
Coetzee, M. \& Potgieter, I.L. (2014). Mediating effect of self-esteem on the career self- management and career resilience of early-career staff in the business management field. Southern African Business Review, 18, 65-82.

Cole, M. \& Cole, S. (2002). E anaptekse ton pedion: Efevia [The development of children: Adolescence]. Athens: Tipothito.

Creed, P. A., Fallon ,T., \& Hood, M. (2009). The relationship between career adaptability, person and situation variables, and career concerns in young adults, Journal of Vocational Behavior, 74, 219-229. https://doi.org/10.1016/j.jvb.2008.12.004

Dimitriou, E. X. (1986). To erotematologio prosopekotitas toy Eysenck: Prosarmoge se elliniko plethismo, enilikes ke pedia [Eysenck Personality Questionnaire: Adaptation in Greek population, adults and children]. Egkefalos, 23, 41-54.

Dries, N., van Esbroeck, R., van Vianen, A.E.M., De Cooman, R., \& Pepermans, R. (2012). Career adapt-abilities scale-Belgium form: Psychometric characteristics and construct validity. Journal of Vocational Behavior, 80, 674-679. https://doi.org/10.1016/j.jvb.2012.01.012

Duarte, M.E., Soares, M.C., Fraga, S., Rafael, M., Lima, M.R., Paredes, I., (...), \& Djaló, A. (2012). Career Adapt-Abilities Scale - Portugal Form: Psychometric properties and relationships to employment status. Journal of Vocational behavior, 80(3), 725-729. Retrieved from https://doi.org/10.1016/j.jvb.2012.01.019

Duffy, R. D. (2010). Sense of control and career adaptability among undergraduate students. Journal of Career Assessment, 18, 1-11. https://doi.org/10.1177/1069072710374587

Eurostat. (2016). Unemployment statistics. Retrieved from http://ec.europa.eu/eurostat/statisticsexplained/index.php/Unemployment_statistics

Fugate, M., \& Kinicki, A. (2008). A dispositional approach to employability: Development of a measure and test of implications for employee reactions to organisational change. Journal of Occupational and Organizational Psychology, 81, 503-527. https://doi.org/10.1348/096317907X241579

Garrety, K., Badham, R., Morrigan, V., Rifkin, W., \& Zanko, M. (2003).The use of personality typing in organizational change: Discourse, emotions and the reflexive subject. Human Relations, 56(2), 211-235. https://doi.org/10.1177/0018726703056002892

Ginevra, M. C., \& Capozza, D. (2015). Il coraggio: dalle definizioni ad alcune considerazioni per le attività di counselling [Courage: From definition to some suggestions for counselling activities]. In L. Nota \& S. Soresi (Eds.), Il counselling del futuro (pp. 111-122). Padova, Italy: Cleup.

Ginevra, M. C., Magnano, P., Lodi, E., Annovazzi, C., Camussi, E., Patrizi, P., \& Nota, L. (2017). The role of career adaptability and courage on life satisfaction in adolescence. Journal of Adolescence, 62, 1-8. https://doi.org/10.1016/j.adolescence.2017.11.002

Graham, J. W. (2009). Missing data analysis: making it work in the real world. Annual Review of Psychology, 60 , 549-576. https://doi.org/10.1146/annurev.psych.58.110405.085530

Han, H., \& Rojewski, J. W. (2015). Gender-specific models of work-bound Korean adolescents' social supports and career adaptability on subsequent job satisfaction. Journal of Career Development, 42, 149-164. https://doi.org/10.1177/08948453145786

Hellenic Statistical Authority. (2015). Labour force survey. http://www.statistics.gr/en/statistics/-/publication/SJO01/2015-Q3

Hirschi, A., \& Läge, D. (2007). Holland's secondary constructs of vocational interests and career choice readiness of secondary students. Journal of Individual Differences, 28, 205-218. https://doi.org/10.1027/1614-0001.28.4.205

Hou, Z., Leung, S. A., Li, X., Li, X., \& Xu, H. (2012). Career adapt-abilities scale - China form: construction and initial validation. Journal of Vocational Behaviour, 80, 686-691. https://doi.org/10.1016/j.jvb.2012.01.006

Hu, L.T., \& Bentler, P.M. (1999). Cutoff criteria for fit indexes in covariance structure analysis: Conventional criteria versus new alternatives. Structural Equation Modeling: A Multidisciplinary Journal, 6, 1-55. https://doi.org/10.1080/10705519909540118 
INE-GSEE. (2015). E ellinike ekonomia ke e apascholise. Etisia Ekthese 2015. [Greek economy and employment. Annual Report 2015].

Johnston, C. S., Luciano, E. C., Maggiori, C., Ruch, W., \& Rossier, J. (2013). Validation of the German version of the career adapt-abilities scale and its relation to orientations to happiness and work stress. Journal of Vocational Behavior , 83, 295-304. https://doi.org/10.1016/j.jvb.2013.06.002

Judge, T.A., Locke, E.A., \& Durham, C.C. (1997). The dispositional causes of job satisfaction: A core evaluations approach. Research in Organizational Behavior, 19, 151-188. https://doi.org/10.1111/j.1464-0597.2007.00318.x

Judge, T.A., van Vianen, A.E.M., \& De Pater, I.E. (2004). Emotional stability, core self-evaluations, and job outcomes: A review of the evidence and an agenda for future research. Human Performance, 17(3), 325-346. https://doi.org/10.1207/s15327043hup1703_4

Koen, J., Klehe, U.-C., \& van Vianen, A.E.M. (2012). Training career adaptability to facilitate a successful school-to-work transition. Journal of Vocational Behavior, 81, 395-408. https://doi.org/10.1016/j.jvb.2012.10.003

Maggiori, C., Johnston, C.-S., Krings, F., Massoudi, K., \& Rossier, J. (2013). The role of career adaptability and work conditions on general and professional well-being. Journal of Vocational Behavior, 83, 437-449. https://doi.org/10.1016/j.jvb.2013.07.001

Mann, M., Hosman, C.M.H., Schaalma, H.P., \& De Vries, N.K. (2004). Self-esteem in a broad-spectrum approach for mental health promotion. Health Education Research, 19, 357-372. https://doi.org/10.1093/her/cyg041

Mason, G., Williams, G., \& Cranmer, S. (2009). Employability skills initiatives in higher education: what effects do they have on graduate labour market outcomes? Education Economics, 17(1), 1-30. https://doi.org/10.1080/09645290802028315

McArdle, S., Waters, L., Briscoe, J. P., \& Hall, D. T. (2007). Employability during unemployment: Adaptability, career identity and human and social capital. Journal of Vocational Behavior, 71, 247-264. https://doi.org/10.1016/j.jvb.2007.06.003

Mylonas, K., Furnham, A., \& Country Collaborators. (2014). Bias in terms of culture and a method for reducing it. An eight-country "Explanations of Unemployment Scale" study. Educational and Psychological Measurement, 74(1), 77-96. https://doi.org/10.1177/0013164413502669

Mylonas, K., Furnham, A., Alvaro, J-L., Papazoglou, S., Divale, W., Cretu, R.Z., ..., \& Boski, P. (2016). Explanations of unemployment: an eight-country comparison. International Journal of Academic Research in Business and Social Sciences, 6(9), 344-357. https://doi.org/10.6007/IJARBSS/v6i9/2315

Mylonas, K., Lawrence, C., Zajenkowska, A., \& Bower Russa, M. (2017). The Situational Triggers of Aggressive Responses scale in five countries: Factor structure and country clustering solutions. Personality and Individual Differences, 104(1), 172-179. Online first. https://doi.org/10.1016/j.paid.2016.07.030

Mylonas, K., Veligekas, P., Gari, A., \& Kontaxopoulou, D. (2012). Development and psychometric properties of the Scale for Self-Consciousness Assessment. Psychological Reports; Measures and Statistics, 111(1), 233-252. https://doi.org/10.2466/08.02.07.PR0.111.4.233-252

Norton, P. J., \& Weiss, B. J. (2009). The role of courage on behavioral approach in a fear-eliciting situation: A proof-of-concept pilot study. Journal of Anxiety Disorders, 23, 212-217. https://doi.org/10.1016/j.janxdis.2008.07.002

Nota, L., Ginevra, M. C. \& Santilli, S. (2015). Life Design and prevention. In L. Nota \& J. Rossier (Eds.), Handbook of Life Design: From practice to theory and from theory to practice (pp. 183-199). Göttingen, Germany: Hogrefe.

Patton, W., \& Creed, P. A. (2001). Developmental issues in career maturity and career decision status. The Career Development Quarterly, 49, 336-351. https://doi.org/10.1002/j.2161-0045.2001.tb00961.x

Petrakis, P. (2012). The Greek economy and the crisis. Challenges and responses. Berlin: Springer-Verlag. https://doi.org/10.1007/978-3-642-21175-1

Porfeli, E. J., \& Savickas, M. L. (2012). Career Adapt-Abilities Scale - USA Form: Psychometric properties and relation to vocational identity. Journal of Vocational Behavior, 80, 748-753. https://doi.org/10.1016/j.jvb.2012.01.009 
Pouyaud, J., Vignoli, E., Dosnon, O., \& Lallemand, N. (2012). Career Adapt-Abilities Scale France form: Psychometric properties and relationships to anxiety and motivation. Journal of Vocational Behaviour, 80, 692-697. https://doi.org/10.1016/j.jvb.2012.01.021

Rosenberg, M. (1965). Society and the adolescent self-image. Princeton, NJ: Princeton University Press. https://doi.org/10.1515/9781400876136

Rossier, J. (2015). Adaptability and life designing. In L. Nota, \& J. Rossier (Eds.), Handbook of life design: From practice to theory and from theory to practice (pp. 153-167). Göttingen: Hogrefe.

Rossier, J., Ginevra, M. C., Bollmann, G., \& Nota, L. (2017). The importance of career adaptability, career resilience, and employability in designing a successful life. In K. Maree (Ed.)., Psychology of career adaptability, employability, and resilience (pp. 65-82). Cham, Switzerland: Springer International Publishing. https://doi.org/10.1007/978-3-319-66954-0_5

Rudolph, C.W., Lavigne, K.N., \& Zacher, H. (2017). Career adaptability: A meta-analysis of relationships with measures of adaptivity, adapting responses, and adaptation results. Journal of Vocational Behavior, 98, 17-34. https://doi.org/10.1016/j.jvb.2016.09.002

Santilli,S., Di Maggio, I., Marcionetti, J., \& Grossen, S. (2018). Life designing and positive youth development. In V. Cohen-Scali, L. Nota, \& J. Rossier (Eds.), New perspectives on career counseling and guidance in Europe. Building careers in changing and diverse societies (pp. 39-51). Cham, Switzerland: Springer International Publishing. https://doi.org/10.1007/978-3-319-61476-2_3

Sarigiannidi, E. (2010). O mathitis empros ste nea epaggelmatike pragmatikotita: Apascholesimotita, Anergia, Pollaples karieres [The student in front of the new career reality: Employability, Unemployment, Multiple Careers]. Epitheorese Symvouleftikis ke Prosanatolesmou, 90-91, 490-494.

Savickas, M. L. (2005). The theory and practice of career construction. In S. D. Brown \& R. W. Lent (Eds.), Career development and counseling: Putting theory and research to work (pp. 42-70). Hoboken, NJ: Wiley.

Savickas, M. L. (2013). Career Construction Theory and Practice. In R. W. Lent \& S. D. Brown (Eds.), Career Development and Counseling: Putting Theory and Research to Work (2nd ed., pp. 144-180). Hoboken, NJ: Wiley.

Savickas, M. L., \& Porfeli, E. J. (2012). Career adapt-abilities scale: construction, reliability, and measurement equivalence across 13 countries. Journal of Vocational Behavior, 80(3), 661-673. https://doi.org/10.1016/j.jvb.2012.01.011

Sidiropoulou-Dimakakou, D., Argyropoulou, K., Drosos, N., Kaliris, A., \& Mikedaki, K. (2015). Exploring career management skills in higher education: Perceived self-efficacy in career, career adaptability and career resilience in Greek university students. International Journal of Learning, Teaching and Educational Research, 14(2), 36-52.

Sidiropoulou-Dimakakou, D., Argyropoulou, K., Mikedaki, K., \& Tsakanika, R. (2013, September). Leaving job stability behind and moving towards career adaptability. A career guidance program for a successful future career. Poster presented at the IAEVG international conference: Career counseling: a human or a citizen's right? International Association for Educational and Vocational Guidance (IAEVG), Montpellier (24-27/9).

Sidiropoulou-Dimakakou, D., Mylonas, K., \& Argyropoulou, K. (2015). Self-efficacy in career planning: A new approach to career exploration. International Journal of Learning, Teaching and Educational Research, 11(2), 40-54.

Soresi, S., Nota, L., \& Ferrari, L. (2012). Career Adapt-abilities Scale-Italian Form: Psychometric properties and relationships to breadth of interests, quality of life, and perceived barriers. Journal of Vocational Behavior, 80, 705-711. https://doi.org/10.1016/j.jvb.2012.01.020

Sovet, L., Annovazzi, C., Ginevra, M. C., Kaliris, A., \& Lodi, E. (2018). Life design in adolescence: The role of positive psychological resources. In V. Cohen-Scali, L. Nota, \& J. Rossier (Eds.), New perspectives on career counseling and guidance in Europe. Building careers in changing and diverse societies (pp. 23-37). Cham, Switzerland: Springer International Publishing. https://doi.org/10.1007/978-3-319-61476-2_2

Sullivan, S.E. \& Mainiero, L.A. (2008). Using the kaleidoscope career model to understand the changing patterns of women's careers: Implementing human resource development programs to attract and retain women. Advances in Developing Human Resources, 10(1), 32-49. https://doi.org/10.1108/13620430910966442 
Sung, Y., Turner, S. L., \& Kaewchinda, M. (2013). Career development skills, outcomes, and hope among

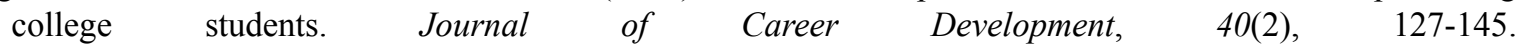
https://doi.org/10.1177/0894845311431939

Tolentino, L., Garcia, P. R. J. M., Lu, V., Restubog, S. L. D., Bordia, P., \& Plewa, C. (2014). Career adaptation: The relation of adaptability to goal orientation, proactive personality, and career optimism. Journal of Vocational Behavior, 84(1), 39 - 48. https://doi.org/10.1016/j.jvb.2013.11.004

Tran, T.T. (2013). Limitation on the development of skills in higher education in Vietnam. Higher Education, 65, 631-644. https://doi.org/10.1007/s10734-012-9567-7

van der Vijver, F., \& Leung, K. (1997). Methods and Data Analysis for CrossCultural Research. London: SAGE Publications.

van Vianen, A.E.M., Klehe, U.-C., Koen, J., \& Dries, N. (2012). Career adapt-abilities scale - Netherlands form: Psychometric properties and relationships to ability, personality, and regulatory focus. Journal of Vocational Behavior, 80, 716-724. https://doi.org/10.1016/j.jvb.2012.01.002

Yuen, M., \& Yau, J. (2015). Relation of career adaptability to meaning in life and connectedness among adolescents in Hong Kong. Journal of Vocational Behavior, 91, 147-156. https://doi.org/10.1016/j.jvb.2015.10.003

Zacher, H. (2014a). Career adaptability predicts subjective career success above and beyond personality traits and core self-evaluations. Journal of Vocational Behavior, 84, 21-30. https://doi.org/10.1016/j.jvb.2013.10.002

\section{Copyrights}

Copyright for this article is retained by the author(s), with first publication rights granted to the journal.

This is an open-access article distributed under the terms and conditions of the Creative Commons Attribution license (http://creativecommons.org/licenses/by/3.0/). 